\title{
CARBON STOCK GROWTH IN A SECONDARY ATLANTIC FOREST
}

Paulo Henrique Villanova ${ }^{2 *}$, Carlos Moreira Miquelino Eleto Torres ${ }^{3}{ }^{\odot}$, Laércio Antônio Gonçalves Jacovine $^{3}{ }^{-}$, Carlos Pedro Boechat Soares ${ }^{3} \odot$, Liniker Fernandes da Silva ${ }^{4} \odot$, Bruno Leão Said Schettini ${ }^{2} \odot$ and $^{\circ}$ Samuel José Silva Soares da Rocha ${ }^{2}$

\footnotetext{
${ }^{1}$ Received on 27.08.2018 accepted for publication on 05.06.2019.

${ }^{2}$ Universidade Federal de Viçosa, Programa de Pós-Graduação em Ciência Florestal, Viçosa, MG- Brasil. E-mail: <paulo.villanova@ufv. br>, <blsschettini@gmail.com> and <samueljoserocha@gmail.com>.

${ }^{3}$ Universidade Federal de Viçosa, Departamento de Engenharia Florestal, Viçosa, MG - Brasil. E-mail: <carlos.eleto@yahoo.com.br>, $<$ jacovine@ufv.br>and <csoares@ufv.br>.

${ }^{4}$ Universidade Federal do Recôncavo da Bahia, Cruz das Almas, BA - Brasil. E-mail: <linikerfs@gmail.com>.

*Corresponding author.
}

\begin{abstract}
The secondary Atlantic forests play an important role in the context of climate change, acting as a carbon sink for the atmosphere. However, these forests can become a carbon source in case of increased tree mortality. Knowing this change is possible through continuous forest inventories that provide information on the dynamics of tree growth. Thus, the objective of this study was to evaluate the carbon growth dynamics of a Seasonal Semideciduous Forest fragment, with 44.11 ha, located in the Parque Tecnológico de Viçosa MG. The forest inventories were carried out in twenty plots of $10 \mathrm{~m} \mathrm{x} 50 \mathrm{~m}$, in the years of 2010 and 2015 , where all stems with $\mathrm{dbh} \geq 5 \mathrm{~cm}$ were measured, botanically identified and classified in ecological groups. The stem volume was obtained through volumetric equation. Biomass and carbon stock were quantified for compartments located above the ground (stem, branches and leaves) and below ground (roots). The dynamics of carbon growth were evaluated by Gross Increment (GI) and Periodic Annual Increment in carbon of the species (PAI). The GI was $12.72 \mathrm{MgC} \mathrm{ha}^{-1}$, including the carbon from the stems that were recruited and died during the monitoring period. The carbon stock increased $10.01 \mathrm{MgC} \mathrm{ha}^{-1}$, resulting in an PAI of $2.00 \mathrm{MgC} \mathrm{ha}^{-1}$ year ${ }^{-1}$. Thus, it is concluded that the forest fragment present positive carbon stock growth due to successional progression, ratifying the importance of secondary forest of the Atlantic forest in the mitigation of greenhouse gases in the atmosphere.
\end{abstract}

Keywords: Climate changes; Forest management; Seasonal Semideciduous Forest.

\section{CRESCIMENTO DO ESTOQUE EM CARBONO EM UMA FLORESTA SECUNDARIA DE MATA ATLÂNTICA}

RESUMO - As florestas secundárias de Mata Atlântica possuem um papel importante no contexto das mudanças climáticas por atuarem como sumidouro de carbono da atmosfera. Entretanto, essas florestas podem se transformar em fonte de carbono com o aumento da mortalidade de árvores. O conhecimento dessa mudança é possível mediante inventários florestais contínuos que forneçam informações sobre a dinâmica de crescimento das árvores. Desta forma, objetivou-se com este estudo avaliar a dinâmica de crescimento em carbono de um fragmento de Floresta Estacional Semidecidual, com 44,11 ha, situado no Parque Tecnológico de Viçosa-MG. Os inventários florestais foram realizados em vinte parcelas de $10 \mathrm{~m} \times 50 \mathrm{~m}$, nos anos de 2010 e 2015, em que todos os fustes com dap $\geq 5 \mathrm{~cm}$ foram mensurados, identificados botanicamente e classificados em grupos ecológicos. O volume do fuste foi obtido por meio de equação volumétrica. A biomassa e o carbono foram quantificados para os compartimentos acima do solo (fuste, galhos e folhas) e abaixo do solo (raízes). A dinâmica de crescimento em carbono foi avaliada por meio do incremento bruto (Ib) e incremento periódico anual em carbono das espécies (IPAli). O Ib foi de 12,72 $\mathrm{MgC} \mathrm{ha}^{-1}$, incluindo o carbono dos fustes que ingressaram e morreram durante o periodo de monitoramento. O estoque de carbono aumentou 10,01 $\mathrm{MgC} \mathrm{ha}^{-1}$, resultando em um IPAli de 2,00 $\mathrm{MgC} \mathrm{ha}^{-1}$ ano $^{-1}$. Assim, conclui-se que as árvores do fragmento florestal apresentam 
crescimento positivo do estoque de carbono em virtude do avanço sucessional, ratificando a importância das florestas secundárias de Mata Atlântica na mitigação de gases de efeito estufa da atmosfera.

Palavras-Chave: Mudanças Climáticas; Manejo Florestal; Floresta Estacional Semidecidual.

\section{INTRODUCTION}

The Atlantic Forest has one of the richest biodiversities in the world, hosting a range of animal and plant species (Joly et al., 2014; Fundação SOS Mata Atlântica and INPE, 2018). This biome also provides a wide range of ecosystem services (Bullock et al., 2011; Ruggiero et al., 2019), such as carbon storage in the multiple compartments of trees and soil (Pan et al., 2011; Delgado et al., 2018).

The Atlantic Forest is able to stock approximately 94.70 $\mathrm{MgC} \mathrm{ha}^{-1}$ in the arboreal individuals, leaving behind only the forests of the Amazonian biome in Brazil (FAO, 2014). In the specific case of seasonal semideciduous forests, recent studies have estimated that carbon stocks in trees can range from $30.99 \mathrm{MgC}$ ha $^{-1}$ (Torres et al., 2017) to $55.91 \mathrm{MgC} \mathrm{ha}^{-1}$ (Silva et al. 2018).

However, the increase of natural disturbance intensity and frequency caused by climate change, such as storms and droughts (Malhi et al., 2008; IPCC, 2014; McDowell et al., 2018) can transform these forests from sink to carbon source for the atmosphere (Malhi et al., 2014; Teixeira et al., 2015; Lu et al., 2019). In this scenario, the tree mortality increase in the leads to a higher carbon loss, surpassing the stock in new individuals and also the growth of remaining trees in a specific period of time (Phillips et al., 2009; Aleixo et al., 2019).

Knowing this change is possible through continuous forest inventories that provide information on the dynamics of forest growth (Souza and Soares, 2013; Teixeira et al., 2016). Besides, the study of the growth dynamics also allows inferring about the transformations occurred in the structures and the floristic composition of the forest (Figueiredo et al., 2013; Meyer et al., 2015) as well as assessing health and the probable impacts from the climate change (Brodie et al., 2012).

In the Atlantic Forest, few studies have attempted to indicate if the forest is acting as a sink or source of carbon for the atmosphere through the growth dynamics (Figueiredo et al., 2015), being the most part restricted in simply estimating the carbon stock (Torres et al., 2013; Carvalho et al., 2015; Diniz et al., 2015). Given this scientific gap, this study aimed to evaluate the dynamics of carbon growth of a secondary forest fragment of the Atlantic Forest.

\section{MATERIAL AND METHODS}

\subsection{Description of the Study area}

The forest fragment size is 44.11 ha and it is located in the Parque Tecnológico de Viçosa - MG, whose geographical coordinates are $42^{\circ} 51^{\prime} \mathrm{W}$ and $20^{\circ}$ 42' S (Torres et al., 2013) in an average altitude of 721 $\mathrm{m}$ (Souza et al., 2014). Its vegetation can be classified as Montana Semideciduous Seasonal Forest (IBGE, 2012). According to the CONAMA resolution 392, the fragment is in the middle stage of regeneration, displaying woody species with an average dbh between 10 and $20 \mathrm{~cm}$, and height between 5 and 12 m (Brazil, 2007).

The local climate is the Cwa type, in the Köppen classification. The average temperature, humidity, and annual rainfall from 1968 to 2015 is $21.9{ }^{\circ} \mathrm{C}, 79 \%$ and 1,274 $\mathrm{mm}$, respectively (UFV, 2016). The region of Viçosa has pedogeomorphologic gradients with aluminum-rich dystrophic latosols at the tops of hills, colluvial ramps with shallow latosols and cambic horizon, while the bottoms of the groves present a predominance of epieutrophic cambisols rich in nutrients (Ferreira Júnior et al., 2012).

Several disturbances have occurred over the years in this forest fragment, such as removal of wood and insertion of agricultural crops and eucalyptus. However, about 25 years ago, it has been occurring the regeneration of its native vegetation (Torres et al., 2013).

\subsection{Data collection and Analysis}

Twenty plots $(10 \mathrm{~m} \times 50 \mathrm{~m})$ were inventoried, in 2010 and 2015, in which all individuals that showed

Revista Árvore 2019;43(4):e430402 
$\mathrm{dbh} \geq 5 \mathrm{~cm}$ were measured and botanically identified. When necessary, the Missouri Botanical Garden (2016) was checked to confirm the scientific names of these species.

The species were classified into ecological groups according to the division proposed by Gandolfi et al. (1995) and used in other studies such as Callegaro et al. (2015), Figueiredo et al. (2013) and Figueiredo et al. (2015), in which they were presented as Pioneer (P), Early Secondary (ES), Late Secondary (LS) and species without classification (SC).

Mortality was recorded in 2015, which corresponds to the individuals that are alive in a specific moment, but are found dead on a second one; and recruitment, which are individuals who reach a minimum inclusion diameter $(\mathrm{dbh} \geq 5 \mathrm{~cm})$ in the last measurement. The recruitment and mortality rates were calculated by the methodology proposed by Ferreira et al. (1998).

The tree component volume was predicted using the equation $\mathrm{VF}_{\mathrm{cc}}=0.000070 * \mathrm{DBH}^{2.204301 *} \mathrm{H}_{\mathrm{t}}^{0.563181}$ $\left(R^{2}=97.04 \%\right.$ and $\left.S_{\mathrm{yx}}=17.4 \%\right)$, in which: $\mathrm{VF}_{\mathrm{cc}}=$ stem volume inside bark $\left(\mathrm{m}^{3}\right), \mathrm{DBH}=$ diameter at breast height $(\mathrm{cm})$ and $\mathrm{H}_{\mathrm{t}}=$ total height $(\mathrm{m})$, adjusted to trees in a Montana Semideciduous Seasonal Forest, located in Viçosa - MG (Amaro, 2010).

For the stem biomass and carbon stock quantification, three trees per specie and diameter class size were selected. Wood samples were removed at $1.30 \mathrm{~m}$ using increment borers. Afterwards, some of the materials were taken to the laboratory to have their wood basic density determined, according to the methodology described by Vital (1984) and NBR 11941 (2003), and the other part was subjected to complete calcination in an muffle furnace to determine the carbon content, according to the methodology described by Torres et al. (2013).

For the branch biomass quantification, a conversion factor $=0.2596$ to convert stem biomass inside bark to branch biomass was used (Amaro, 2010; Amaro et al., 2013; Torres et al., 2013). Conversion factor equal to 0.0445 was used for the foliage component (Drumond, 1997; Amaro et al., 2013; Torres et al., 2013). In both cases, the carbon stock was obtained by multiplying the biomass by $48.54 \%$, which corresponds to the average carbon content found by Amaro (2010) for the same forest typology.
For the roots, it was considered that this component corresponds to $24 \%$ of the stem biomass (Amaro et al., 2013; Torres et al., 2013). The carbon stock was quantified considering the same content used for the branches and leaves. This way, the total carbon stock of the fragment for 2010 and 2015 was obtained by the sum of the carbon stock above the ground (stem, branches, leaves) plus the carbon stock below the ground (roots).

The Gross Increment (GI) in carbon of the forest fragment (growth) was obtained through the equation: $\mathrm{GI}=\left(\mathrm{C}_{\mathrm{f}}-\mathrm{R}\right)-\left(\mathrm{C}_{\mathrm{i}}-\mathrm{M}\right)$, in which: $\mathrm{GI}=$ gross increment, excluding the recruitment, in $\mathrm{MgC} \mathrm{ha}{ }^{-1} ; \mathrm{C}_{\mathrm{f}}=$ carbon stock at the end of the period, in $\mathrm{MgC} \mathrm{ha}^{-1} ; \mathrm{C}_{\mathrm{i}}=$ carbon stock at the beginning of the period, in $\mathrm{MgC} \mathrm{ha}^{-1} ; \mathrm{R}=$ recruitment of stems, resulting in the growth of stored carbon, in $\mathrm{MgC} \mathrm{ha}^{-1} ; \mathrm{M}=$ mortality of stems, resulting in loss of stored carbon, in $\mathrm{MgC} \mathrm{ha}^{-1}$ (Davis; Johnson, 1987; Figueiredo et al., 2015).

The Periodic Annual Increment in carbon (PAI), by species, was calculated by the following equation: PAI $=\left(\mathrm{C}_{\mathrm{f}}-\mathrm{C}_{\mathrm{i}}\right) / \mathrm{t}$, in which: $\mathrm{PAI}=$ periodic annual increment per species, in $\mathrm{MgC} \mathrm{ha}{ }^{-1} \mathrm{ano}^{-1} ; \mathrm{C}_{\mathrm{f}}=$ carbon stock at the end of the period, in $\mathrm{MgC} \mathrm{ha}^{-1} ; \mathrm{C}_{\mathrm{i}}=$ carbon stock at the beginning of the period, in $\mathrm{MgC} \mathrm{ha}^{-1} ; \mathrm{t}=$ time gap, in years. The Periodic Annual Increment in carbon per stem was calculated through the following equation: $\mathrm{PAI}_{\text {stem }}=\mathrm{PAI} / \mathrm{SD}_{\mathrm{i}}$, in which: $\mathrm{PAI}_{\text {stem }}=$ periodic annual increment per stem, in $\mathrm{MgC}^{\text {stem }}{ }^{-1}$ year ${ }^{-1} ; \mathrm{SD}_{\mathrm{i}}=$ stems density of each species, in stems ha $^{-1}$ (Figueiredo et al., 2015).

\section{RESULTS}

During the monitoring period (2010-2015), the total number of stems ha ${ }^{-1}$ increased from 1526 to 1692 (Figure 1), including the mortality of 169 stems $\mathrm{ha}^{-1}$ and the recruitment of 335 stems $^{-1}$. This way, the mortality rate of the studied species was $2.00 \%$ each year, while the recruitment rate was 3.96\% each year.

The biomass and the carbon stock had an increase of $19.51 \mathrm{Mg} \mathrm{ha}^{-1}$ and $10.01 \mathrm{MgC} \mathrm{ha}^{-1}$, respectively, during the assessed monitored period (Table 1).

The carbon accumulation was higher in the early secondary species and in the first diameter classes. In this ecological group, the carbon accumulation was 5.77 $\mathrm{MgC} \mathrm{ha}^{-1}$, while for the pioneer, unclassified, and late secondary species, it was $2.86 \mathrm{MgC} \mathrm{ha}^{-1}, 0.53$ $\mathrm{MgC} \mathrm{ha} \mathrm{h}^{-1}$ and $0.85 \mathrm{MgC} \mathrm{ha}^{-1}$, respectively (Table 2).

Revista Árvore 2019;43(4):e430402 


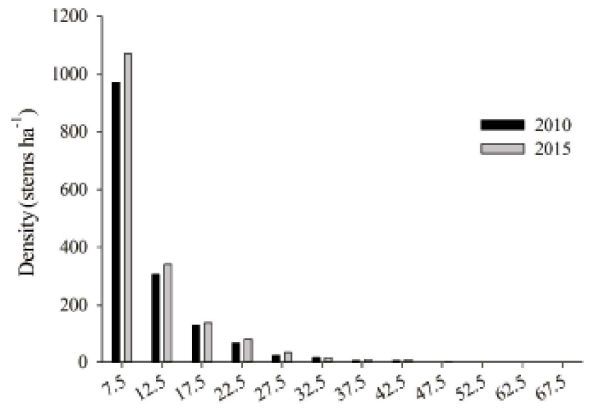

Diameter Class (cm)

Figure 1 - Diameter distribution of the species, in stems ha ${ }^{-1}$, for the years 2010 and 2015.

Figura 1 - Distribuição diamétrica das espécies, em fustes ha-1, para os anos de 2010 e 2015.

The Gross Increment (GI) in carbon of the forest fragment (growth) was $12.72 \mathrm{MgC} \mathrm{ha}^{-1}$, considering carbon lost by mortality and carbon stocked by recruitment (Figure 2).

The Periodic Annual Increment in carbon (PAI) was $2.00 \mathrm{MgC} \mathrm{ha}^{-1}$ year $^{-1}$. The species

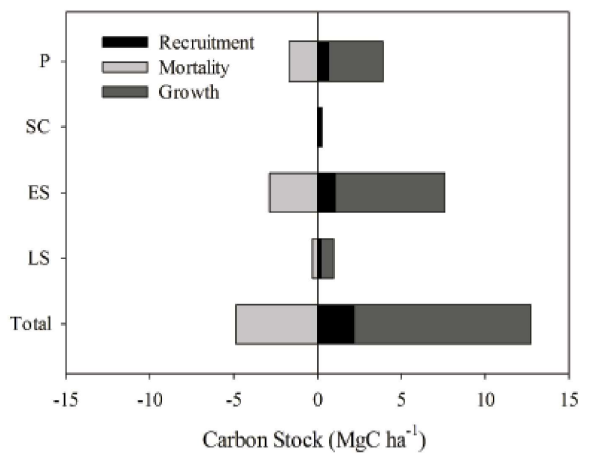

Figure 2 - Carbon stock growth, by ecological group, for the monitoring period, in which: P - pioneer species; SC unclassified species; ES - early secondary species; LS late secondary species; Total - sum of ecological groups.

Figura 2 - Crescimento do estoque em carbono, por grupo ecológico, para o período de monitoramento, em que: $\mathrm{P}$ - espécie pioneira; $\mathrm{SC}$ - espécie sem classificação; ES - espécie secundária inicial; LS - espécie secundária tardia; Total - somatório dos grupos ecológicos.

that presented higher PAI were the Piptadenia gonoacantha, Anadenanthera peregrina, Myrcia fallax, Matayba elaeagnoides and Sparattosperma leucanthum (Table 3).

Table 1 - Biomass $\left(\mathrm{Mg} \mathrm{ha}^{-1}\right)$ and carbon stock $\left(\mathrm{MgC} \mathrm{ha}^{-1}\right)$ for the monitored period (mean \pm standard deviation).

Tabela 1-Biomassa $\left(M g h a^{-1}\right)$ e estoque de carbono $\left(M g C h a^{-1}\right)$ para o periodo de monitoramento (média \pm desvio padrão)

\begin{tabular}{|c|c|c|c|c|}
\hline & \multicolumn{2}{|c|}{ Biomass } & \multicolumn{2}{|c|}{ Carbon } \\
\hline & 2010 & 2015 & 2010 & 2015 \\
\hline Above the ground & $86.23 \pm 1.90$ & $102.71 \pm 1.87$ & $44.85 \pm 1.00$ & $53.40 \pm 0.98$ \\
\hline Under the ground & $15.87 \pm 0.35$ & $18.90 \pm 0.34$ & $7.70 \pm 0.17$ & $9.18 \pm 0.17$ \\
\hline Total & $102.10 \pm 2.25$ & $121.61 \pm 2.21$ & $52.56 \pm 1.17$ & $62.57 \pm 1.15$ \\
\hline
\end{tabular}

Table 2 - Carbon stock $\left(\mathrm{MgC} \mathrm{ha}^{-1}\right)$ by ecological group and by class center for the monitoring period.

Tabela 2 - Estoque de carbono $\left(\mathrm{MgC} \mathrm{ha}^{-1}\right)$ por grupo ecológico e por centro de classe para o período de monitoramento.

\begin{tabular}{|c|c|c|c|c|c|c|c|c|c|c|c|c|c|}
\hline \multirow[t]{2}{*}{ GE } & \multicolumn{12}{|c|}{ Class Center } & \multirow[t]{2}{*}{ Total } \\
\hline & 7.5 & 12.5 & 17.5 & 22.5 & 27.5 & 32.5 & 37.5 & 42.5 & 47.5 & 52.5 & 62.5 & 67.5 & \\
\hline \multicolumn{14}{|c|}{------------------2010------------------ } \\
\hline $\mathrm{P}$ & 2.21 & 3.20 & 3.58 & 2.72 & 1.35 & 0.79 & 0.86 & 0.59 & - & - & 0.46 & 0.86 & 15.77 \\
\hline $\mathrm{SC}$ & 0.03 & 0.06 & 0.06 & 0.14 & 0.10 & 0.20 & - & - & - & - & - & - & 0.59 \\
\hline ES & 4.15 & 4.73 & 4.80 & 4.98 & 2.74 & 4.03 & 1.68 & 2.78 & 1.14 & 1.39 & - & 1.68 & 32.40 \\
\hline LS & 0.89 & 0.61 & 0.51 & 0.60 & 0.36 & 0.36 & 0.47 & - & - & - & - & 0.47 & 3.81 \\
\hline Total & 7.29 & 8.60 & 8.95 & 8.44 & 4.55 & 5.37 & 3.01 & 3.37 & 1.14 & 1.39 & 0.46 & 3.01 & 52.56 \\
\hline \multicolumn{14}{|c|}{------------------2015------------------- } \\
\hline $\mathrm{P}$ & 2.20 & 2.93 & 4.45 & 3.78 & 2.26 & 0.51 & 0.97 & 1.51 & - & - & - & - & 18.63 \\
\hline $\mathrm{SC}$ & 0.06 & 0.08 & 0.10 & 0.15 & 0.12 & 0.62 & - & - & - & - & - & - & 1.12 \\
\hline ES & 5.01 & 6.30 & 5.00 & 5.90 & 4.16 & 4.04 & 2.08 & 2.76 & 1.76 & 1.17 & - & - & 38.17 \\
\hline LS & 1.17 & 0.83 & 0.34 & 0.54 & 0.55 & 0.42 & 0.82 & - & - & - & - & - & 4.66 \\
\hline Total & 8.44 & 10.13 & 9.88 & 10.38 & 7.09 & 5.59 & 3.87 & 4.27 & 1.76 & 1.17 & - & - & 62.57 \\
\hline
\end{tabular}

In which: GE - ecological group; P - pioneer species; SC - unclassified species; ES - early secondary species; LS - late secondary species; Total - sum by ecological group and by class center.

Em que: GE - grupo ecológico; P-espécie pioneira; SC-espécie sem classificação; ES-espécie secundária inicial; LS-espécie secundária tardia; Total-somatório por grupo ecológico e por centro de classe.

\section{Revista Árvore 2019;43(4):e430402}




\section{DISCUSSION}

In the observed period (2010-2015), the number of individuals recruited (335 stems ha ${ }^{-1}$ ) was higher than mortality ( $\left.169 \mathrm{stems} \mathrm{ha}^{-1}\right)$, corresponding to a rate of $3.96 \%$ and $2.00 \%$ per year, respectively. When we analyze the Figure 1, the stems mortality was observed in the last diameter classes, while the recruitment occurred mainly in the first classes. Moreover, there was an increase in the number of stems ha-1 in this period, from 1526, in 2010, to 1692, in 2015.

This growth dynamic of the forest fragment was driven mainly by intrinsic factors to the community, such as topography and geology of the place, the species characteristics and the forest successional stage (Xu et al., 2016; Ma et al., 2016). Due to the short monitoring time, it was not possible to notice the contribution of the climatic factors, despite being present in this process (Kardol et al., 2010; Zhang et al., 2015).

In terms of biomass and carbon, an increase of 19.51 $\mathrm{Mg} \mathrm{ha}^{-1}$ and $10.01 \mathrm{MgC} \mathrm{ha}^{-1}$, respectively, was observed in the monitoring period. This increase in the accumulation of biomass and in the carbon stock is justified by the forest successional (Souza et al., 2012), leading to a greater richness of non-pioneer species with higher wood density (Fonseca et al., 2011; Shimamoto et al., 2014).
This is corroborated by Diniz et al. (2015) who, when studying two fragments of Submontana Semideciduous Seasonal Forest, obtained a carbon stock of $20.9 \mathrm{MgC} \mathrm{ha}^{-1}$ for the forest during middle succession stage and $70.6 \mathrm{MgC} \mathrm{ha}^{-1}$ for the forest during advanced succession stage. In case of Souza et al. (2012), they found a carbon stock of $36.54 \mathrm{MgC}$ $\mathrm{ha}^{-1}$ and $75.25 \mathrm{MgC} \mathrm{ha}^{-1}$ for fragments of Submontana Semideciduous Seasonal Forest during middle and medium/advanced stages, respectively. Thus, it is expected that, over the years, the fragment may increase its capacity to store carbon until the forest ecosystem enters a dynamic balance (Oliveira et al., 2014).

The effects of forest succession on the carbon stock were better noticed when analyzing Table 2 . Although there was an increase in total carbon stock in all ecological groups, it was observed that, for the pioneer species, there was a decrease in the first diameter classes in the monitoring period. Among the possible causes for this finding are the low number of recruitment due to the fact that these species no longer tolerate shading condition (Ma et al., 2016), and also because of the high mortality due to the competition for resources (Chazdon, 2008). On the other hand, the carbon stock by non-pioneer species was ascending in the first diameter classes.

Table 3 - Gross increment $\left(\mathrm{MgC} \mathrm{ha}^{-1}\right)$ and periodic annual increment in carbon by species $\left(\mathrm{MgC} \mathrm{ha}^{-1} \mathrm{year}^{-1}\right)$ and by stem $\left(\mathrm{MgC} \mathrm{stem}^{-1}\right.$ year $\left.{ }^{-1}\right)$ for the monitoring period.

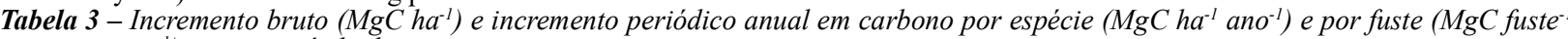
ano ${ }^{-1}$ ) para o período de monitoramento.

\begin{tabular}{|c|c|c|c|c|c|c|c|c|c|}
\hline Species & GE & SDi & $\mathrm{Cf}$ & $\mathrm{R}$ & $\mathrm{Ci}$ & M & GI & PAI & PAI $_{\text {stem }}$ \\
\hline Piptadenia gonoacantha & $\mathrm{P}$ & 103 & 7.90 & 0.12 & 6.81 & 0.55 & 1.52 & 0.22 & 0.0021 \\
\hline Anadenanthera peregrina & $\mathrm{Si}$ & 41 & 7.68 & 0.04 & 6.99 & 0.14 & 0.78 & 0.14 & 0.0033 \\
\hline Myrcia fallax & $\mathrm{Si}$ & 99 & 3.08 & 0.08 & 2.48 & 0.25 & 0.78 & 0.12 & 0.0012 \\
\hline Matayba elaeagnoides & $\mathrm{Si}$ & 99 & 1.53 & 0.12 & 1.02 & 0.06 & 0.46 & 0.10 & 0.0010 \\
\hline Sparattosperma leucanthum & $\mathrm{Si}$ & 15 & 1.48 & 0.00 & 1.08 & 0.00 & 0.39 & 0.08 & 0.0053 \\
\hline Hieronyma alchorneoides & $\mathrm{Si}$ & 4 & 1.54 & 0.00 & 1.15 & 0.00 & 0.39 & 0.08 & 0.0193 \\
\hline Casearia ulmifolia & $\mathrm{Si}$ & 21 & 1.73 & 0.02 & 1.37 & 0.02 & 0.37 & 0.07 & 0.0035 \\
\hline Platypodium elegans & $\mathrm{Si}$ & 26 & 2.62 & 0.02 & 2.29 & 0.14 & 0.45 & 0.07 & 0.0026 \\
\hline Apuleia leiocarpa & $\mathrm{Si}$ & 44 & 2.82 & 0.01 & 2.51 & 0.05 & 0.35 & 0.06 & 0.0014 \\
\hline Annona sp. & $\mathrm{Si}$ & 24 & 1.31 & 0.01 & 1.00 & 0.10 & 0.39 & 0.06 & 0.0060 \\
\hline$\cdots$ & $\cdots$ & $\cdots$ & $\cdots$ & $\cdots$ & $\cdots$ & $\cdots$ & $\cdots$ & $\cdots$ & $\ldots$ \\
\hline Total & - & 1692 & 62.57 & 2.18 & 52.56 & 4.89 & 12.72 & 2.00 & 0.0012 \\
\hline
\end{tabular}

In which: GE - Ecologic Group; P - pioneer species; ES - early secondary species; SDi - stems density (stem ha $\left.{ }^{-1}\right)$; $\mathrm{Cf}$ - final carbon $\left(\mathrm{MgC} \mathrm{ha}^{-1}\right)$; $\mathrm{R}$ - recruitment $(\mathrm{MgC}$ $\left.\mathrm{ha}^{-1}\right) ; \mathrm{Ci}$ - initial carbon $\left(\mathrm{MgC} \mathrm{ha}^{-1}\right) ; \mathrm{M}$ - mortality $\left(\mathrm{MgC} \mathrm{ha}^{-1}\right)$; GI - gross increment $\left(\mathrm{MgC} \mathrm{ha}^{-1}\right)$; PAI - periodic annual increment per species $\left(\mathrm{MgC} \mathrm{ha}^{-1}\right.$ year $\left.{ }^{-1}\right)$; PAI periodic annual increment per stem $\left(\mathrm{MgC} \mathrm{stem}^{-1}\right.$ year $\left.^{-1}\right)$.

Em que: GE - Grupo Ecológico; P - espécie pioneira; $E S$ - espécie secundária inicial; SDi-densidade de fustes (fuste ha $\left.{ }^{-1}\right)$; $C f$ - carbono final $\left(M g C h a^{-1}\right)$; $R$ - ingresso

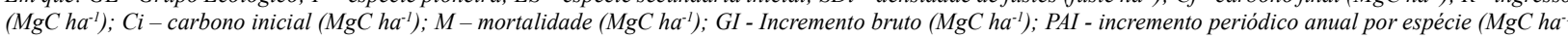

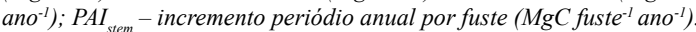


This upward stock contributed to carbon growth of the fragment, that was $12.72 \mathrm{MgC} \mathrm{ha}^{-1}$. Of this total, about $60 \%$ was due to the growth of the early secondary species (Figure 2). This ecological dominance of early secondary species on carbon growth was also a reflection of the successional progression of the forest fragment.

Considering the period evaluated (2010 to 2015), it was found a periodic annual increment in carbon (PAI) of $2.00 \mathrm{MgC} \mathrm{ha}^{-1}$ year $^{-1}$. In a study by Figueiredo et al. (2015), in a semideciduous seasonal forest, in the middle stage of regeneration, it was found an estimate of PAI in carbon of $0.994 \mathrm{MgC} \mathrm{ha}^{-1}$ year $^{-1}$, from 1994 to 2008 , considering only the stem. Souza et al. (2011) found an PAI in carbon of $0.14 \mathrm{MgC} \mathrm{ha}^{-1}$ year $^{-1}$ for a semideciduous seasonal forest, also in the middle stage of regeneration, from 2002 to 2007 , considering stems and branches. The PAI estimates found by these authors were much lower than those found in this study. One of the causes that may have influenced this low PAI is the non-quantification of components, such as leaves and roots, to which they are relevant in the carbon stock of tropical forests (Watzlawick et al., 2012; Torres et al., 2013).

The PAI in carbon by species indicated that Piptadenia gonoacantha (P), Anadenanthera peregrina (ES), Myrcia fallax (ES), Matayba elaeagnoides (ES) and Sparattosperma leucanthum (ES) distinguished themselves in relation to other species. Together, these five species accounts for $33 \%$ of the fragment's PAI. The knowledge over the species that have the greatest potential in storing carbon allows to guide forestry managers on floristic composition, in forest restoration projects or in carbon neutralization plantations in regions whose soil and climatic conditions are similar to that of the studied fragment. This way, the mitigation capacity of these areas can be intensified, making them large atmosphere carbon sinks.

\section{CONCLUSIONS}

The trees of the forest fragment had carbon stock growth (2.00 $\mathrm{MgC} \mathrm{ha}^{-1}$ year-1 $^{-1}$ due to successional progression. The species that most contribute to the removal of carbon are Piptadenia gonoacantha, Anadenanthera peregrina, Myrcia fallax, Matayba elaeagnoides and Sparattosperma leucanthum. This fact corroborates that, even in the face of climate change, the secondary Atlantic Forests play an important role as a carbon sink and, consequently, in the reduction of the greenhouse gas concentration in the atmosphere.

\section{ACKNOWLEDGEMENT}

We would like to thank the Conselho Nacional de Desenvolvimento Científico e Tecnológico (CNPq), the Coordenação de Aperfeiçoamento de Pessoal de Nível Superior (CAPES) and the Fundação de Amparo à Pesquisa do Estado de Minas Gerais (FAPEMIG) for the research funding. We would also like to thank the study group in economy and forest management (GEEA) for their assistance with data collection. To the Parque Tecnológico de Viçosa and CENTEV for the concession of the study area.

\section{REFERENCES}

Aleixo I, Norris D, Hemerik L, Barbosa A, Prata E, Costa $\mathrm{F}$, et al. Amazonian rainforest tree mortality driven by climate and functional traits. Nature Climate Change. 2019;9(1):384-88. doi:10.1038/ s41558-019-0458-0.

Teixeira KJA, Davies SJ, Bennett AC, GonzalezAkre EB, Muller-Landau HC, Joseph Wright S, et al. CTFS-Forest GEO: a worldwide network monitoring forests in an era of global change. Global change biology. 2015;21(2):528-49. doi:10.1111/gcb.12712.

Teixeira KJA, Wang MM, McGarvey JC, LeBauer DS. Carbon dynamics of mature and regrowth tropical forests derived from a pantropical database (TropForC-db). Global change biology. 2016;22(5):1690-09. doi:10.1111/gcb.13226.

Amaro MA. Quantificação do estoque volumétrico, de biomassa e de carbono em uma Floresta Estacional Semidecidual no Município de Viçosa-MG [tese]. Viçosa: Universidade Federal de Viçosa; 2010.

Amaro MA, Soares CPB, Souza ALD, Leite HG, Silva GFD. Estoque volumétrico, de biomassa e de carbono em uma Floresta Estacional Semidecidual em Viçosa, Minas Gerais. Revista Árvore. 2013;37(5):849-57. doi:10.1590/S010067622013000500007. 
Associação Brasileira de Normas Técnicas - ABNT. NBR 11941: Densidade básica da madeira. Brasília; 2003.

Brasil. Resolução n 392, de 25 junho de 2007. Definição de vegetação primária e secundária de regeneração de Mata Atlântica no Estado de Minas Gerais. Brasília, DF: Ministério do Meio Ambiente/ Conselho Nacional de Meio Ambiente; 2007.

Brodie J, Post E, Laurance WF. Climate change and tropical biodiversity: a new focus. Trends in ecology \& evolution. 2012;27(3):145-50. doi:10.1016/j. tree.2011.09.008.

Bullock JM, Aronson J, Newton AC, Pywell RF, Rey-Benayas JM. Restoration of ecosystem services and biodiversity: conflicts and opportunities. Trends in Ecology \& Evolution. 2011;26(10):541-49. doi:10.1016/j.tree.2011.06.011.

Callegaro RM, Longhi SJ, Andrzejewski C. Variações estruturais entre grupos florísticos de um remanescente de Floresta Ombrófila Mista Montana em Nova Prata-RS. Ciência Florestal. 2015;25(2):337-49. doi:10.5902/1980509818452.

Carvalho LS, Cerqueira RM, Silva GV, Silva ERM. Estoque de carbono em um fragmento de Floresta Estacional Semidecídua no município de Ribeirão Grande, São Paulo. Bioikos. 2015;28(2):73-85.

Chazdon RL. Chance and determinism in tropical forest sucession. In: Carson WP, Schnitzer SA. Tropical forest community ecology. Chichester: Blackwell Publishing Ltd; 2008.

Davis LS, Johnson KN. Forest management. 3rd ed. New York: McGraw-Hill Book; 1987.

Delgado RC, Pereira MG, Teodoro PE, Santos GL, Carvalho DC, Magistrali IC, et al. Seasonality of gross primary production in the Atlantic Forest of Brazil. Global Ecology and Conservation. 2018;14(1):e00392. doi:10.1016/j.gecco.2018. $\mathrm{e} 00392$.

Diniz AR, Machado DL, Pereira MG, Carvalho FC, Menezes CEG. Biomassa, estoques de carbono e de nutrientes em estádios sucessionais da Floresta Atlântica, RJ. Revista Brasileira de Ciências Agrárias. 2015;10(3):443-51. doi:10.5039/agraria. v10i3a4264.
Drumond MA, Barros ND, Souza AD, Silva AD. Distribuição de biomassa e nutrientes em diferentes coberturas florestais e pastagem na região do Médio Rio Doce-MG. Revista Árvore. 1997;21(2):187-99.

Ferreira Júnior WG, Schaeffer CEGR, Silva AF. Uma visão pedogeomorfológica sobre as formações florestais da Mata Atlântica. In: Martins SV. Ecologia de florestas tropicais do Brasil. Viçosa: Editora UFV; 2012.

Ferreira RLC, Souza AL, Jesus RM. Ingresso e mortalidade em floresta secundária de transição. Revista Árvore. 1998;22(2):155-62.

Figueiredo LTM, Soares CPB, Souza AL, Martins SV. Alterações florísticas em uma Floresta Estacional Semidecidual, no município de Viçosa, MG, entre 1994 e 2008. Floresta. 2013;43(2):169-80. doi:10.5380/rf.v43i2.28869.

Figueiredo LTM, Soares CPB, Souza AL, Leite HG, Silva GFD. Dinâmica do estoque de carbono em fuste de árvores de uma floresta estacional semidecidual. Cerne. 2015;21(1):161-67. doi:10.159 0/01047760201521011529.

Fonseca W, Benayas JMR, Alice FE. Carbon accumulation in the biomass and soil of different aged secondary forests in the humid tropics of Costa Rica. Forest Ecology and Management. 2011;262(8):1400-08. doi:10.1016/j. foreco.2011.06.036.

Fundação SOS Mata Atlântica \& INPE. Atlas dos remanescentes florestais da Mata Atlântica período 2016-2017; 2018. Relatório Técnico.

Food and Agriculture Organization of the United Nations - FAO. FRA2015 Brazil, Country Report; 2014. [cited 2019 sep 10]. Available from: http:// www.fao.org/3/a-az172e.pdf.

Gandolfi S, Leitão-Filho HF, Bezerra CL. Levantamento florístico e caráter sucessional de espécies arbustivo-arbóreas de uma floresta Mesófila Semidecídua no município de Guarulhos, SP. Revista Brasileira de Biologia. 1995;55(4):753-67.

Intergovernmental Panel on Climate Change - IPCC. Climate change 2014: mitigation of climate change. Cambridge University Press; 2014.

\section{Revista Árvore 2019;43(4):e430402}


Instituto Brasileiro de Geografia e Estatística - IBGE. Manual Técnico da Vegetação Brasileira. $2^{\mathrm{a}}$ ed. Rio de Janeiro; 2012.

Joly CA, Metzger JP, Tabarelli M. Experiences from the Brazilian Atlantic Forest: ecological findings and conservation initiatives. New Phytologist. 2014;204(3):459-73. doi:10.1111/nph.12989.

Kardol P, Todd DE, Hanson PJ, Mulholland PJ. Long-term successional forest dynamics: species and community responses to climatic variability. Journal of Vegetation Science. 2010;21(4):627-42. doi:10.1111/j.1654-1103.2010.01171.x.

Lu C, Tian H, Zhang J, Yu Z, Pan S, Dangal S, et al. Severe long-lasting drought accelerated carbon depletion in the Mongolian Plateau. Geophysical Research Letters. 2019:46. doi:10.1029/2018GL081418.

Ma L, Lian J, Lin G, Cao H, Huang Z, Guan D. Forest dynamics and its driving forces of subtropical forest in South China. Scientific reports. 2016;6(1):22561. doi:10.1038/srep22561.

McDowell N, Allen CD, Teixeira KA, Brando $\mathrm{P}$, Brienen R, Chambers J, et al. Drivers and mechanisms of tree mortality in moist tropical forests. New Phytologist. 2018;219(3):851-69. doi:10.1111/nph.15027.

Malhi Y, Roberts JT, Betts RA, Killeen TJ, Li W, Nobre CA. Climate change, deforestation, and the fate of the Amazon. Science. 2008;319(5860):16972. doi:10.1126/science. 1146961 .

Malhi Y, Gardner TA, Goldsmith GR, Silman MR, Zelazowski P. Tropical forests in the Anthropocene. Annual Review of Environment and Resources. 2014;39(1):125-59. doi:10.1146/annurevenviron-030713-155141.

Tropicos.org. Missouri Botanical Garden. [cited 2019 sep 10]. Available from: http://www.tropicos. org. 2016.

Meyer PB, Oliveira-Filho AT, Botezelli L, Aurélio M, Fontes L, Garcia PO, et al. Dinâmica estrutural em um fragmento de Floresta Estacional Semideciduifólia em Lavras, MG, Brasil. Cerne. 2015;21(2):259-65. doi:10.1590/010477602015210 21711.
Oliveira APD, Schiavini I, Vale VSD, Lopes SDF, Arantes CDS, Gusson AE, et al. Mortality, recruitment and growth of the tree communities in three forest formations at the Panga Ecological Station over ten years (1997-2007). Acta Botanica Brasilica. 2014;28(2):234-48. doi:10.1590/S010233062014000200010 .

Pan Y, Birdsey RA, Fang J, Houghton R, Kauppi PE, Kurz WA, et al. 2011. A large and persistent carbon sink in the world's forests. Science. 2011;333(6045):988-93. doi:10.1126/ science. 1201609.

Phillips OL, Aragão LE, Lewis SL, Fisher JB, Lloyd J, López-González G, et al. Drought sensitivity of the Amazon rainforest. Science. 2009;323(5919):134447. doi:10.1126/science. 1164033.

Ruggiero PGC, Metzger JP, Tambosi LR, Nichols E. Payment for ecosystem services programs in the Brazilian Atlantic Forest: Effective but not enough. Land Use Policy. 2019;82(1):283-91. doi:10.1016/j. landusepol.2018.11.054.

Shimamoto CY, Botosso PC, Marques MC. How much carbon is sequestered during the restoration of tropical forests?. Estimates from tree species in the Brazilian Atlantic forest. Forest Ecology and Management. 2014;329(1):1-9. doi:10.1016/j. foreco.2014.06.002.

Silva HF, Ribeiro SC, Botelho SA, Liska GR, Cirillo MA. Biomass and Carbon in a Seasonal Semideciduous Forest in Minas Gerais. Floresta e Ambiente. 2018;25(1):e20160508. doi:10.1590/2179-8087.050816.

Souza ALD, Boina A, Soares CPB, Vital BR, Gaspar RDO, Lana JMD. Estoque e crescimento em volume, biomassa, carbono e dióxido de carbono em floresta Estacional Semidecidual. Revista Árvore. 2011;35(6):1277-85. doi:10.1590/S010067622011000700014.

Souza AL, Boina A, Soares CPB, Vital BR, Gaspar RO, Lana JM. Estrutura fitossociológica, estoques de volume, biomassa, carbono e dióxido de carbono em Floresta Estacional Semidecidual. Revista Árvore. 2012;36(1):169-179. doi:10.1590/S010067622012000100018.

Souza AL, Soares CPB. Florestas nativas: estrutura, dinâmica e manejo. Viçosa, MG: Editora UFV; 2013. 
Souza LFT, Fernandes Filho EI, Faria MM. Compartimentação geomorfológica e mapeamento digital de solos no município de Viçosa-MG. Revista Geonorte. 2014;5(16):110-14.

Torres CMME, Jacovine LAG, Soares CPB, Oliveira Neto SN, Santos RD, Castro Neto F. Quantificação de biomassa e estocagem de carbono em uma Floresta Estacional Semidecidual, no Parque Tecnológico de Viçosa, MG. Revista Árvore. 2013;37(4):647-55. doi:10.1590/S010067622013000400008 .

Torres CMME, Jacovine LAG. Oliveira Neto SN, Souza AL, Campos RA, Schettini BLS. Análise fitossociológica e valor de importância em carbono para uma Floresta Estacional Semidecidual. Floresta e Ambiente. 2017;24:e0099714. doi:10.1590/2179. 8087.099714.

Universidade Federal de Viçosa - UFV.

Departamento de Engenharia Agrícola. Estação Climatológica Principal de Viçosa. Boletim meteorológico de 2016. Viçosa; 2016.

Vital BR. Métodos de determinação de densidade da madeira. Viçosa: SIF/UFV; 1984.

Xu B, Pan Y, Plante AF, Johnson A, Cole J, Birdsey $\mathrm{R}$. Decadal change of forest biomass carbon stocks and tree demography in the Delaware River Basin. Forest Ecology and Management. 2016;374(1):1-10. doi:10.1016/j.foreco.2016.04.045.

Zhang J, Huang S, He F. Half-century evidence from western Canada shows forest dynamics are primarily driven by competition followed by climate. Proceedings of the National Academy of Sciences. 2015;112(13):4009-14. doi:10.1073/ pnas. 1420844112 .

Watzlawick LF, Caldeira MVW, Viera M, Schumacher MV, Godinho TDO, Balbinot R. Estoque de biomassa e carbono na Floresta Ombrófila Mista Montana, Paraná. Scientia Forestalis. 2012;40(95):353-62. 